Pobrane z czasopisma Studia Iuridica Lublinensia http://studiaiuridica.umes.pl Data: 26/04/2023 11:31:36

Artykuły

Studia Iuridica Lublinensia vol. XXVI, 1, 2017

DOI: 10.17951/sil.2017.26.1.399

\title{
Michał Hejbudzki
}

Uniwersytet Warmińsko-Mazurski w Olsztynie

mhejbudzki@uwm.edu.pl

\section{Normatywne struktury funkcjonowania podmiotów gospodarczych w mechanizmie dopłat do prywatnego przechowywania na rynku wieprzowiny}

The Normative Provisions for the Operators Participating in Private Storage Aid Mechanism for the Pigmeat Market

\section{STRESZCZENIE}

Przedmiotem rozważań zawartych w artykule są normatywne struktury funkcjonowania podmiotów gospodarczych w mechanizmie dopłat do prywatnego przechowywania na rynku wieprzowiny, wyznaczone przede wszystkim rozporządzeniem Parlamentu Europejskiego i Rady (UE) nr 1308/2013 z dnia 17 grudnia 2013 r. ustanawiającym wspólną organizację rynków produktów rolnych oraz uchylającym rozporządzenia Rady (EWG) nr 922/72, (EWG) nr 234/79, (WE) nr 1037/2001 i (WE) nr 1234/2007, a także obowiązującym od 1 października 2016 r. rozporządzeniem delegowanym KE (UE) 2016/1238 z dnia 18 maja 2016 r. uzupełniającym rozporządzenie Parlamentu Europejskiego i Rady (UE) nr 1308/2013 w odniesieniu do interwencji publicznej i dopłat do prywatnego przechowywania oraz rozporządzeniem wykonawczym KE (UE) 2016/1240 z dnia 18 maja 2016 r. ustalającym zasady stosowania rozporządzenia Parlamentu Europejskiego i Rady (UE) nr 1308/2013 w odniesieniu do interwencji publicznej i dopłat do prywatnego przechowywania. biorca

Słowa kluczowe: dopłaty do prywatnego przechowywania; rynek wieprzowiny; przedsię- 


\section{WPROWADZENIE}

Fundamentem funkcjonowania Wspólnej Polityki Rolnej (WPR) są branżowe rynki rolne ${ }^{1}$. Jednym $\mathrm{z}$ nich jest rynek wieprzowiny ${ }^{2}$. W celu zapewnie-

${ }^{1}$ P. Czechowski, Europejskie rynki rolne, [w:] Prawo rolne, Warszawa 2011, s. 381-382; B. Jeżyńska, Branżowa organizacja rynków rolnych, [w:] Prawo rolne i żywnościowe. Zarys wykładu, red. B. Jeżyńska, A. Oleszko, Kraków 2003, s. 245; K. Kozikowska, Agencja Rynku Rolnego i organizacja niektórych rynków rolnych, [w:] Prawo rolne, red. M. Jarosiewicz, K. Kozikowska, Kraków 2007, s. 177.

2 P. Czechowski, Proces dostosowywania polskiego prawa rolnego i żywnościowego do prawa Unii Europejskiej, Warszawa 2001, s. 206-207; M. Szewczak, Administracyjno-prawne aspekty realizacji Wspólnej Polityki Rolnej w Polsce, Lublin 2008, s. 130. Normatywne regulacje rynku wieprzowiny są liczne i wielokrotnie się zmieniały. Spośród aktów prawnych o podstawowym znaczeniu dla tego rynku należy wymienić przede wszystkim rozporządzenie Rady nr 121/67/EWG (5) z dnia 13 czerwca 1967 r. w sprawie wspólnej organizacji rynku wieprzowiny (Dz.Urz. 117 z 19 czerwca 1967 r., s. 2283-2293), uchylone przez art. 28 ust. 1 rozporządzenia Rady (EWG) nr 2759/75 z dnia 29 października 1975 r. w sprawie wspólnej organizacji rynku wieprzowiny (Dz.Urz. L 282 z 1 listopada 1975 r., s. 1), zmienionego rozporządzeniem (WE) nr 1365/2000 (Dz.Urz. L 156 z 29 czerwca 2000 r., s. 5) i uchylonego przez art. 201 ust. 1 pkt c rozporządzenia Rady (WE) nr 1234/2007 z dnia 22 października 2007 r. ustanawiającego wspólną organizację rynków rolnych oraz przepisy szczegółowe dotyczące niektórych produktów rolnych („rozporządzenie o jednolitej wspólnej organizacji rynku”, Dz.Urz. L 299 z 16 listopada 2007 r., s. 1-149), które z kolei w zasadniczej części utraciło moc na podstawie art. 230 ust. 1 rozporządzenia Parlamentu Europejskiego i Rady (UE) nr 1308/2013 z dnia 17 grudnia 2013 r. ustanawiającego wspólną organizację rynków produktów rolnych oraz uchylającego rozporządzenia Rady (EWG) nr 922/72, (EWG) nr 234/79, (WE) nr 1037/2001 i (WE) nr 1234/2007. Z punktu widzenia rozpatrywanego w niniejszym opracowaniu instrumentu prawnego, jakim jest dopłata do prywatnego przechowywania, godzi się wymienić rozporządzenie Komisji (EWG) nr 1092/80 z dnia 2 maja 1980 r. ustanawiające szczegółowe zasady przyznawania pomocy w odniesieniu do prywatnego składowania wieprzowiny (Dz.Urz. L 114 z 3 maja 1980 r., s. 22), które utraciło moc na podstawie art. 17 rozporządzenia Komisji (EWG) nr 3444/90 z dnia 27 listopada 1990 r. ustanawiającego szczegółowe zasady dotyczące przyznawania pomocy w odniesieniu do prywatnego składowania wieprzowiny (Dz.Urz. L 333 z 30 listopada 1990 r., s. 22-29) i uchylonego przez art. 42 rozporządzenia Komisji (WE) nr 826/2008 z dnia 20 sierpnia 2008 r. ustanawiającego wspólne zasady dotyczące przyznawania dopłat do prywatnego przechowywania niektórych produktów rolnych (Dz.Urz. L 223 z 21 sierpnia 2008 r., s. 3-22), które z kolei zostało uchylone przez art. 10 obecnie obowiązującego rozporządzenia delegowanego KE (UE) 2016/1238 z dnia 18 maja 2016 r. uzupełniającego rozporządzenie Parlamentu Europejskiego i Rady (UE) nr 1308/2013 w odniesieniu do interwencji publicznej i dopłat do prywatnego przechowywania (Dz.Urz. L 206 z 30 lipca 2016 r., s. 15-43). Tytułem uzupełnienia wypada dodatkowo wskazać na szereg innych aktów prawnych o tymczasowym charakterze, które następnie zostały przez Komisję zaliczone do grona przestarzałych aktów prawa unijnego w zakresie rolnictwa (zob. Komunikat Komisji Europejskiej oficjalnie uznający za przestarzałe niektóre akty prawa unijnego w zakresie rolnictwa, Cel czwarty komunikatu Komisji z dnia 11 lutego 2003 r. w sprawie aktualizacji i uproszczenia wspólnotowego dorobku prawnego COM(2003) 71 wersja ostateczna, Dz.Urz. C 336 z 11 grudnia 2010 r., s. 1-32). Należy tu wskazać: rozporządzenie Komisji (WE) nr 2042/98 z dnia 25 września 1998 r. w sprawie specjalnych warunków przyznawania pomocy w odniesieniu do prywatnego przechowywania wieprzowiny (Dz.Urz. L 263 z 26 września 1998 r., s. 12-14); roz- 
nia równowagi i stabilizacji cen poszczególnych rynków oraz odpowiedniego poziomu życia ludności wiejskiej w prawodawstwie unijnym zostały wypracowane zróżnicowane systemy wsparcia rynkowego dla poszczególnych sektorów i wprowadzono systemy wsparcia bezpośredniego przy uwzględnieniu z jednej strony różnych potrzeb każdego z tych sektorów, a z drugiej zależności zachodzących między nimi.

Do głównych mechanizmów interwencyjnych w UE, występujących na rynku wieprzowiny, należy interwencja publiczna oraz dopłaty do prywatnego przechowywania ${ }^{3}$. Zadaniem dopłat do prywatnego przechowywania jest okresowe zablokowanie nadwyżek wieprzowiny na rynku w sytuacji, gdy nadmierna podaż powoduje niekorzystne relacje cenowe. W przeciwieństwie do interwencji publicznej w systemie dopłat do prywatnego przechowywania nie następuje przeniesienie własności wieprzowiny na agencję płatniczą. W zamian za dopłatę z tytułu przechowywania przedsiębiorca zobowiązuje się do składowania produktu przez czas określony w umowie i powstrzymania się od wprowadzenia go na rynek ${ }^{4}$.

Zmieniająca się sytuacja na rynkach rolnych oraz nowe wyzwania zaowocowały pracami zmierzającymi do reformy WPR, której jednym z kluczowych zadań stało się wprowadzenie skuteczniejszych i sprawniej działających sieci bezpieczeństwa dla sektorów najbardziej narażonych na kryzysy, opartych m.in. na systemie prywatnego przechowywania ${ }^{5}$. Wyrazem tej reformy stało się m.in.

porządzenie Komisji (WE) nr 2713/1999 z dnia 20 grudnia 1999 r. wprowadzające odstępstwo od rozporządzenia (EWG) nr 3444/90 ustanawiającego szczegółowe zasady dotyczące przyznawania pomocy w odniesieniu do prywatnego składowania wieprzowiny (Dz.Urz. L 327 z 21 grudnia 1999 r., s. 31-32); rozporządzenie Komisji (WE) nr 2179/2002 z dnia 6 grudnia 2002 r. w sprawie szczególnych warunków przyznawania pomocy w odniesieniu do prywatnego składowania wieprzowiny (Dz.Urz. L 331 z 7 grudnia 2002 r., s. 11-12); rozporządzenie Komisji (WE) nr 2246/2003 z dnia 19 grudnia $2003 \mathrm{r}$. w sprawie szczególnych warunków przyznawania pomocy w odniesieniu do prywatnego składowania wieprzowiny (Dz.Urz. L 333 z 20 grudnia 2003 r., s. 34-36); rozporządzenie Komisji (WE) nr 1267/2007 z dnia 26 października 2007 r. w sprawie szczególnych warunków przyznawania pomocy w odniesieniu do prywatnego składowania wieprzowiny (Dz.Urz. L 283 z 27 października 2007 r., s. 53-54); rozporządzenie Komisji (WE) nr 179/2008 z dnia 28 lutego 2008 r. umożliwiające przedłużenie okresu obowiązywania umów o prywatne przechowywanie w sektorze wieprzowiny (Dz.Urz. L 56 z 29 lutego 2008 r., s. 3-13); rozporządzenie Komisji (WE) nr 1278/2008 z dnia 17 grudnia 2008 r. w sprawie przyjęcia nadzwyczajnych środków wsparcia rynku wieprzowiny w formie dopłat do prywatnego przechowywania w Irlandii (Dz.Urz. L 339 z 18 grudnia 2008 r., s. $78-81)$.

${ }^{3}$ E. Tomkiewicz, Dopłaty z tytułu prywatnego przechowywania produktów rolnych, [w:] Wspólna polityka rolna. Zagadnienia prawne, red. A. Jurcewicz, B. Kozłowska, E. Tomkiewicz, Warszawa 2007, s. 85-86; idem, Dopłaty do prywatnego przechowywania produktów rolnych, [w:] Prawo i polityka rolna Unii Europejskiej, red. A. Jurcewicz, Warszawa 2010, s. 63-64.

${ }^{4}$ P. Zaręba, E. Bolisęga, Nowe zasady interwencji na rynkach rolnych Unii Europejskiej, „Biuletyn Informacyjny ARR” 2016, nr 2, s. 22.

${ }^{5}$ Komunikat Komisji Europejskiej z dnia 12 października 2011 r., http://europa.eu/rapid/ press-release_IP-11-1181_pl.htm [dostęp: 15.10.2016]. 
rozporządzenie Parlamentu Europejskiego i Rady (UE) nr 1308/2013 z dnia 17 grudnia 2013 r. ustanawiające wspólną organizację rynków produktów rolnych oraz uchylające rozporządzenia Rady (EWG) nr 922/72, (EWG) nr 234/79, (WE) nr 1037/2001 i (WE) nr 1234/20076. Przyczyną wprowadzenia tego rozporządzenia było m.in. usprawnienie, rozszerzenie i uproszczenie przepisów na podstawie dotychczasowych doświadczeń związanych z prywatnym przechowywaniem?

Wahania na rynku wieprzowiny w poszczególnych okresach czasowych wymuszały stosowanie przez Komisję UE instrumentów interwencyjnych w postaci dopłat do prywatnego przechowywania zarówno przed wejściem w życie rozporządzenia 1308/2013 ${ }^{8}$, jak i później9.

${ }^{6}$ Dz.Urz. L 347 z 20 grudnia 2013 r., s. 671-854, dalej jako: rozporządzenie 1308/2013.

7 Zob. uzasadnienie wniosku rozporządzenia Parlamentu Europejskiego i Rady ustanawiające wspólną organizację rynków produktów rolnych (,rozporządzenie o jednolitej wspólnej organizacji rynków”), COM/2011/0626, wersja ostateczna - 2011/0281 (COD), http://eur-lex.europa. eu/legal-content/PL/TXT/?uri=CELEX:52011PC0626 [dostęp: 15.10.2016].

${ }^{8}$ Zob. np. rozporządzenie wykonawcze Komisji (UE) nr 68/2011 z dnia 28 stycznia 2011 r. w sprawie ustalania $z$ wyprzedzeniem stawek dopłat do prywatnego przechowywania wieprzowiny (Dz.Urz. L 26 z 29 stycznia 2011 r., s. 2-4) oraz związane z nim rozporządzenie wykonawcze Komisji (UE) nr 192/2011 z dnia 25 lutego 2011 r. ustanawiające specjalne środki w odniesieniu do dopłat do prywatnego przechowywania wieprzowiny przewidzianych w rozporządzeniu (UE) nr 68/2011 (Dz.Urz. L 53 z 26 lutego 2011 r., s. 65-65) i rozporządzenie wykonawcze Komisji (UE) nr 197/2011 z dnia 28 lutego 2011 r. ustanawiające ostateczny termin składania wniosków o przyznanie dopłat z tytułu przechowywania wieprzowiny na mocy rozporządzenia (UE) nr 68/2011 (Dz.Urz. L 56 z 1 marca 2011 r., s. 9-19).

${ }^{9}$ W latach 2014-2015 zostało odnotowane pogorszenie sytuacji unijnego sektora wieprzowiny. W tym okresie, ze względu na specyfikę rynku wieprzowiny, w którego system wpisane jest nieuniknione opóźnienie $\mathrm{w}$ dostosowaniu sektora hodowlanego do spadku popytu na tusze wieprzowe, unijna produkcja świń wzrosła, podczas gdy dobrze do tej pory funkcjonujący wywóz poważnie się zmniejszył na skutek utraty Rosji jako rynku eksportowego. Przykładem polityki interwencyjnej Komisji UE opartej na mechanizmie dopłat do prywatnego przechowywania w tym czasie było rozporządzenie wykonawcze Komisji (UE) 2015/360 z dnia 5 marca 2015 r. wprowadzające prywatne przechowywanie wieprzowiny oraz ustalające z góry stawkę dopłat (Dz.Urz. L 62 z 6 marca 2015 r., s. 16-19), a także związane z nim: rozporządzenie wykonawcze Komisji (UE) 2015/679 z dnia 29 kwietnia 2015 r. zawieszające składanie wniosków o dopłaty do prywatnego przechowywania wieprzowiny przewidziane w rozporządzeniu wykonawczym Komisji (UE) 2015/360 (Dz.Urz. L 111 z 30 kwietnia 2015 r., s. 27-27) oraz rozporządzenie wykonawcze Komisji (UE) 2015/725 z dnia 5 maja 2015 r. ustanawiające ostateczny termin składania wniosków o przyznanie dopłat do prywatnego przechowywania wieprzowiny na mocy rozporządzenia wykonawczego (UE) 2015/360 (Dz.Urz. L 115 z 6 maja 2015 r., s. 32-33). Po raz drugi widocznym działaniem Komisji UE stało się rozporządzenie wykonawcze 2015/2334 z dnia 14 grudnia 2015 r. wprowadzające prywatne przechowywanie wieprzowiny oraz ustalające z góry stawkę dopłat (Dz.Urz. L 329 z 15 grudnia 2015 r., s. 10-13) oraz związane z nimi: rozporządzenie wykonawcze 2016/85 z dnia 25 stycznia 2016 r. zawieszające składanie wniosków o przyznanie dopłat do prywatnego przechowywania wieprzowiny przewidzianych w rozporządzeniu wykonawczym (UE) 2015/2334 (Dz.Urz. L 17 z 26 stycznia 2016 r., s. 10-11) i rozporządzenie wykonawcze 2016/132 z dnia 1 lutego 2016 r. ustanawiające ostateczny termin składania wniosków o przyznanie dopłat do prywatnego przechowywania wieprzowiny na mocy rozporządzenia wykonawczego (UE) 
Od 1 października 2016 r. obowiązują też dwie nowe ważne regulacje w zakresie dopłat do prywatnego przechowywania, tj. rozporządzenie delegowane KE (UE) 2016/1238 z dnia 18 maja 2016 r. uzupełniające rozporządzenie Parlamentu Europejskiego i Rady (UE) nr 1308/2013 w odniesieniu do interwencji publicznej i dopłat do prywatnego przechowywania ${ }^{10}$ oraz rozporządzenie wykonawcze KE (UE) 2016/1240 z dnia 18 maja 2016 r. ustalające zasady stosowania rozporządzenia Parlamentu Europejskiego i Rady (UE) nr 1308/2013 w odniesieniu do interwencji publicznej i dopłat do prywatnego przechowywania ${ }^{11}$. Ostatnim z wymienionych aktów prawnych zostały uchylone dotychczasowe wspólne zasady dotyczące przyznawania dopłat do prywatnego przechowywania niektórych produktów rolnych ${ }^{12}$.

Ze względu na powyższe fakty celem niniejszego opracowania jest analiza obecnie obowiązujących ram prawnych wyznaczających funkcjonowanie przedsiębiorców w mechanizmie dopłat do prywatnego przechowywania na rynku wieprzowiny.

\section{ZASADY URUCHAMIANIA DOPŁAT DO PRYWATNEGO PRZECHOWYWANIA WIEPRZOWINY}

Normatywną podstawę przyznawania dopłat do prywatnego przechowywania wieprzowiny stanowi art. 17 pkt h rozporządzenia 1308/2013, które jednocześnie w art. 19-21 uprawnia Komisję do regulowania szeregu czynników kształtujących ten rynek ${ }^{13}$.

2015/2334 (Dz.Urz. L 25 z 2 lutego 2016 r., s. 56-57). Jak się okazało, zastosowane działania miały pozytywny wpływ na rynek wieprzowiny i postępującą stabilizację cen. Przykładowo na mocy wymienionych aktów prawnych z 2016 r. ARR zawarła 60 umów na 5928 ton wieprzowiny, tj. 7\% całkowitej ilości w UE. Zob. Informacja Ministra Rolnictwa i Rozwoju Wsi na temat realizacji działań Agencji Rynku Rolnego w zakresie pakietu pomocowego Komisji Europejskiej, Warszawa 2016, www.senat.gov.pl/gfx/senat/userfiles/_public/k9/komisje/2016/krrw/ materialy/25pos/25pos_infmrrw.pdf [dostęp: 16.10.2016], s. 12.

${ }_{10}$ Dz.Urz. L 206 z 30 lipca 2016 r., s. 15-43, dalej jako: rozporządzenie 2016/1238. Rozporządzenie weszło w życie siódmego dnia po jego opublikowaniu w Dzienniku Urzędowym Unii Europejskiej, natomiast stosuje się je od dnia 1 października 2016 r. Jednakże jeżeli chodzi o zakup w ramach interwencji publicznej, część II załącznika I stosuje się od dnia 1 lipca 2017 r.

${ }^{11}$ Dz.Urz. L 206 z 30 lipca 2016, s. 71-127, dalej jako: rozporządzenie 2016/1240. Rozporządzenie weszło w życie siódmego dnia po jego opublikowaniu w Dzienniku Urzędowym Unii Europejskiej, natomiast stosuje się je od dnia 1 października 2016 r. Jednak w odniesieniu do zakupów w ramach interwencji publicznej tabele III i IV części V oraz lit. b części VI załącznika I stosuje się od dnia 1 lipca 2017 r.

${ }_{12}$ Zob. uwagi do rozporządzenia Komisji (WE) nr 826/2008 przytoczonego w przypisie 1.

${ }^{13}$ Komisja jest uprawniona m.in. do przyjmowania aktów delegowanych określających warunki, na jakich może ona podejmować decyzje o przyznaniu dopłat do prywatnego przechowywania, a także może przyjmować akty wykonawcze przyznające dopłaty do prywatnego prze- 
Komisja, w razie konieczności, jest uprawniona do przyjmowania aktów delegowanych określających warunki, na jakich może ona podejmować decyzje o przyznaniu dopłat do prywatnego przechowywania produktów wymienionych w art. 17, uwzględniając średnie ceny rynkowe notowane w Unii, progi referencyjne i koszty produkcji danych produktów oraz potrzebę zareagowania we właściwym czasie na szczególnie trudną sytuację na rynku lub na zmiany sytuacji gospodarczej, które mają znaczący negatywny wpływ na marże w sektorze. Komisja może przyjmować akty wykonawcze przyznające dopłaty do prywatnego przechowywania oraz ograniczające przyznawanie tych dopłat.

Decyzja o uruchomieniu dopłat leży w sferze kompetencji Komisji. Sposób ustalania wielkości dopłat do prywatnego przechowywania określa art. 4 rozporządzenia Rady (UE) nr 1370/2013 z dnia 16 grudnia 2013 r. Rozporządzenie to określa środki dotyczące ustalania niektórych dopłat i refundacji związanych ze wspólną organizacją rynków produktów rolnych ${ }^{14}$. W celu określenia kwoty pomocy na prywatne przechowywanie wieprzowiny uruchamia się na określony czas procedurę przetargową albo ustala się wysokość dopłat z wyprzedzeniem. Pomoc może być ustalona na państwo członkowskie lub region państwa członkowskiego. Komisja przyjmuje akty wykonawcze: a) w przypadku, gdy ma zastosowanie procedura przetargowa - określające maksymalną kwotę pomocy na prywatne przechowywanie, b) w przypadku, gdy pomoc jest ustalana z wyprzedzeniem - określające kwotę pomocy na podstawie kosztów przechowywania lub innych odpowiednich czynników rynkowych.

Szczegółowe zasady przyznawania dopłat do prywatnego przechowywania zostały określone w przepisach rozporządzenia 2016/1238 i rozporządzenia 2016/1240. Jednakże jeszcze przed ich przybliżeniem wypada zwrócić uwagę na fakt, że przepisy rozporządzenia 1308/2013 konsekwentnie posługują się terminem ,podmiot prywatny"15 $\mathrm{w}$ odniesieniu do beneficjenta dopłat z tytułu prywatnego przechowywania. Tymczasem na gruncie przepisów rozporządzenia

chowywania oraz ograniczające przyznawanie dopłat do prywatnego przechowywania. Ponadto Komisja jest uprawniona do określania m.in. przepisów i warunków stosowanych w przypadkach, gdy ilość przechowywana jest mniejsza od ilości przewidzianej w umowie; warunków przyznawania zaliczek dotyczących takich dopłat; warunków, na jakich można podjąć decyzję o ponownym wprowadzeniu do obrotu lub o zbywaniu produktów objętych umowami prywatnego przechowywania; przepisów przewidujących stosowanie procedur przetargowych gwarantujących równy dostęp do towarów i równe traktowanie podmiotów gospodarczych, jak również do przyjmowania środków dotyczących: zawierania i treści umów o prywatnym przechowywaniu między właściwym organem państwa członkowskiego a wnioskodawcami; wprowadzania produktów do prywatnego przechowywania, ich prywatnego przechowywania oraz wycofania z przechowywania; długości okresu prywatnego przechowywania oraz przepisów, na podstawie których okres ten, określony w umowie, może zostać skrócony lub wydłużony; stosowania procedur przetargowych.

${ }^{14}$ Dz.Urz. L 346 z 20 grudnia 2013 r., s. 12-19.

${ }^{15} \mathrm{~W}$ innych wersjach językowych pojęcie to brzmi: franc. les opérateurs, ang. private operators, niem. private Marktteilnehmer. 
2016/1238 i rozporządzenia 2016/1240 katalog podmiotów mogących uczestniczyć w systemie dopłat do prywatnego przechowywania został oparty na podwójnym kryterium podmiotowym. Pierwsze z nich polega na włączeniu do tego mechanizmu tylko podmiotów, które są podmiotami gospodarczymi ${ }^{16}$, zaś drugie wprowadza dodatkowe ograniczenie w postaci obowiązku posiadania siedziby i rejestracji do celów podatku VAT w Unii ${ }^{17}$. Uprawniony wydaje się pogląd, że $\mathrm{w}$ polskim systemie prawnym desygnatem występującego $\mathrm{w}$ unijnych regulacjach pojęcia „podmiot gospodarczy” jest przedsiębiorca. Pod pojęciem tym, w omawianym kontekście, należy też rozumieć rolników, których zarówno doktryna ${ }^{18}$, jak i judykatura ${ }^{19} \mathrm{w}$ pewnych sytuacjach zalicza do przedsiębiorców.

Zdarzeniem otwierającym procedurę przetargową lub ustalającym z góry stawki dopłat jest rozporządzenie, którego treść zawiera dane wymienione w art. 39 rozporządzenia 2016/1240. Przedsiębiorcy składają oferty przetargowe i wnioski o dopłaty do prywatnego przechowywania za pomocą metody udostępnionej przez agencję płatniczą właściwego państwa członkowskiego. Daje to podstawę do wyróżnienia dwóch trybów, w wyniku których dochodzi do związania stron umową na dopłaty do prywatnego przechowywania wieprzowiny.

\section{PRZESŁANKI ZAWARCIA UMOWY W TRYBIE PROCEDURY PRZETARGOWEJ I W WYNIKU USTALANIA Z GÓRY STAWKI DOPŁAT}

Ważność oferty przetargowej lub wniosku jest uwarunkowana złożeniem dokumentów w języku urzędowym lub jednym z języków urzędowych państwa członkowskiego, w którym są składane. Muszą one zawierać, w formularzu udostępnionym przez agencję płatniczą, przynajmniej następujące informacje: nazwę przedsiębiorcy, adres i numer identyfikacyjny VAT w państwie członkowskim jego głównej działalności; produkt lub rodzaj produktu, w stosownych przypadkach z obejmującym go kodem CN; ilość, jakiej dotyczy oferta przetargowa lub wniosek, w stosownych przypadkach podlegająca ilościom minimalnym. Oferta przetargowa lub wniosek o dopłaty do prywatnego przechowywania są ważne, jeżeli spełniają przedstawione wymogi oraz zawierają przynajmniej następujące in-

${ }^{16} \mathrm{~W}$ innych wersjach językowych pojęcie to brzmi: franc. les opérateurs, ang. operators, niem. die Marktteilnehmer.

${ }^{17} \mathrm{~W}$ warunkach polskich od przedsiębiorców ponadto wymagana jest rejestracja w Centralnym Rejestrze Przedsiębiorców prowadzonym przez ARR.

${ }^{18}$ R. Budzinowski, Status prawny rolnika jako przedsiębiorcy. Zagadnienia wybrane, „Ruch Prawniczy, Ekonomiczny i Socjologiczny" 2002, nr 3, s. 111-120; J. Naworski, Status prawny rolnika indywidualnego, „Przegląd Prawa Handlowego” 2012, nr 10, s. 11-19; B. Jeżyńska, Producent rolny jako przedsiębiorca, Lublin 2008, s. 143.

${ }_{19}$ Zob. uchwała SN z dnia 26 lutego 2015 r., III CZP 108/14, OSNC 2016, nr 1, poz. 2; wyrok SN z dnia 3 października 2014 r., V CSK 630/13, OSNC 2015, nr 7-8, poz. 96. 
formacje: odniesienie do rozporządzenia wykonawczego otwierającego procedurę przetargową lub ustalającego z góry stawki dopłat do prywatnego przechowywania; okres przechowywania, o ile wymaga tego rozporządzenie wykonawcze otwierające procedurę przetargową lub ustalające $\mathrm{z}$ góry stawki dopłat do prywatnego przechowywania; ilość produktów objętą ofertą przetargową lub wnioskiem; w przypadku produktów już przechowywanych, nazwę i adres każdego z miejsc prywatnego przechowywania, umiejscowienie poszczególnych partii, kadzi i silosów w miejscu przechowywania wraz odpowiadającymi im ilościami, a w stosownych przypadkach numer identyfikacyjny zatwierdzonego przedsiębiorstwa; w przypadku ofert przetargowych - datę wygaśnięcia podokresów ich składania, jak również kwotę dopłaty w euro na jednostkę miary danego produktu zaokrągloną do nie więcej niż dwóch miejsc po przecinku, bez uwzględnienia podatku VAT.

Oferta przetargowa i wniosek nie mogą zawierać żadnych dodatkowych warunków wprowadzonych przez przedsiębiorcę, wykraczających poza te ustanowione w rozporządzeniu 2016/1240 lub w odpowiednim rozporządzeniu wykonawczym otwierającym procedurę przetargową lub ustalającym z góry stawki dopłat do prywatnego przechowywania. Ofert przetargowych i wniosków nie wycofuje się ani nie zmienia po ich złożeniu. Agencja płatnicza rejestruje ważne oferty przetargowe lub wnioski wraz $\mathrm{z}$ ujętymi w nich ilościami w dniu ich wpłynięcia. Prawa i obowiązki wynikające z przyjęcia oferty przetargowej lub wniosku nie podlegają przeniesieniu.

Bezpieczeństwo mechanizmu dopłat do prywatnego przechowywania wspierane jest co do zasady obowiązkiem wniesienia przez przedsiębiorcę zabezpieczenia na rzecz odpowiedniej agencji płatniczej ${ }^{20}$ przy składaniu oferty przetargowej lub wniosku o dopłatę do prywatnego przechowywania, chyba że w rozporządzeniu wykonawczym otwierającym procedurę przetargową lub ustalającym z góry stawki dopłat określono inaczej. Art. 5 rozporządzenia 2016/1238 zawiera katalog przypadków, w których zabezpieczenie zostaje zwolnione albo ulega przepadkowi.

Agencja płatnicza decyduje o ważności przedłożonych ofert przetargowych i wniosków, zaś państwa członkowskie powiadamiają Komisję o wszystkich ważnych ofertach przetargowych i wnioskach.

Na podstawie ofert przetargowych, o których powiadomiono Komisję, decyduje ona o nieustalaniu lub ustalaniu maksymalnej kwoty pomocy. Decyzja w sprawie pomocy jest publikowana w Dzienniku Urzędowym UE. W pierwszym przypadku wszystkie oferty przetargowe zostają odrzucone, w drugim zaś agencja płatnicza przyjmuje oferty równe tej kwocie lub od niej niższe, ale akceptacji podlegają tylko te oferty, o których powiadomiono Komisję. Agencja płatnicza powiadamia przedsiębiorców o wyniku ich udziału w procedurze prze-

${ }^{20}$ W Polsce mechanizm dopłat do prywatnego przechowywania został włączony w zakres kompetencyjny Agencji Rynku Rolnego. 
targowej w ciągu 3 dni roboczych od wejścia w życie wspomnianej decyzji Komisji. Otrzymanie przez przedsiębiorcę takiego powiadomienia rodzi dla niego dwa obowiązki. Po pierwsze, jest to obowiązek powiadomienia agencji płatniczej o terminie przyjęcia produktów do miejsca przechowywania, nazwie i adresie każdego z miejsc prywatnego przechowywania i odpowiednich ilościach. Informacje te muszą wpłynąć do agencji płatniczej przynajmniej na 5 dni przed rozpoczęciem wprowadzania pierwszej partii produktów do przechowywania, aczkolwiek agencja płatnicza może przyjąć okres skrócony poniżej 5 dni roboczych. Po drugie, jeżeli produkt do tej pory nie był przechowywany, należy go wprowadzić do przechowywania w ciągu 28 dni po otrzymaniu powiadomienia.

$\mathrm{W}$ odniesieniu do procedury zawarcia umowy w wyniku ustalania z góry stawki dopłat na uwagę zasługują dodatkowo dwa zagadnienia.

Po pierwsze, w przypadku produktów już przechowywanych ważny wniosek uznaje się za zaakceptowany ósmego dnia roboczego po wpłynięciu tego wniosku. Natomiast w przypadku produktów dotąd nieprzechowywanych agencja płatnicza powiadamia przedsiębiorcę o decyzji w sprawie zaakceptowania ważnego wniosku ósmego dnia roboczego po wpłynięciu tego wniosku. Wówczas przedsiębiorca ma obowiązek powiadomienia agencji płatniczej o terminie przyjęcia produktów do miejsca przechowywania, nazwie i adresie każdego z miejsc prywatnego przechowywania i odpowiednich ilościach. Informacje te muszą wpłynąc do agencji płatniczej przynajmniej na 5 dni przed rozpoczęciem wprowadzania pierwszej partii produktów do przechowywania. Agencja płatnicza może przyjąć okres skrócony poniżej 5 dni roboczych. Dodatkowo, jeżeli produkt do tej pory nie był przechowywany, należy go wprowadzić do przechowywania w ciągu 28 dni po otrzymaniu powiadomienia.

Po drugie, jeżeli analiza sytuacji wykazuje nadużycie systemu prywatnego przechowywania lub wskazuje na groźbę nadużycia bądź spekulacji, Komisja może zadecydować: a) o zawieszeniu stosowania systemu na nie więcej niż 5 dni roboczych; wnioski złożone w tym okresie zostają odrzucone, b) ustaleniu jednolitego współczynnika procentowego, o jaki zmniejszone będą ilości wskazane we wnioskach, w stosownych przypadkach, z zastrzeżeniem zachowania minimalnych ilości objętych umową (w takiej sytuacji przedsiębiorca może podjąc decyzję o wycofaniu swojej oferty w ciągu 10 dni roboczych od daty wejścia w życie decyzji ustalającej współczynnik procentowy redukcji), c) odrzuceniu wniosków złożonych przed okresem zawieszenia, których zaakceptowanie przypadałoby na okres zawieszenia. 


\section{UMOWA NA DOPŁATY DO PRYWATNEGO PRZECHOWYWANIA WIEPRZOWINY}

Umowę na dopłaty do prywatnego przechowywania należy uznać za wyodrębnioną umowę posiadającą swój własny reżim prawny. Argumentu o autonomicznym charakterze tej umowy dostarcza również wykładnia lingwistyczna polskiego tłumaczenia tytułu rozdziału II rozporządzenia 2016/1240, który brzmi Umowy przechowywania, a nie „przechowania” 21 .

Istotą tej umowy jest zobowiązanie się przedsiębiorcy względem agencji płatniczej do przechowywania stanowiącego jego własność wieprzowiny przez czas określony w umowie i niewprowadzanie tego produktu na rynek w tym okresie w zamian za dopłaty finansowe. Nie jest przy tym wymagane, aby przechowywanie odbywało się w chłodniach należących do przedsiębiorcy. Może on zawrzeć umowę składu z przedsiębiorcą składowym, przy czym składowanie musi odbywać się zgodnie ze standardami wyznaczonymi przepisami o dopłatach do prywatnego przechowywania.

Umowy takie są zawierane między agencją płatniczą państwa członkowskiego, na którego terytorium produkty są lub będą przechowywane, a przedsiębiorcami, których ofertę przetargową lub wniosek przyjęto. Jeżeli ilość faktycznie wprowadzona do przechowywania wynosi poniżej 95\% ilości wskazanych w ofercie przetargowej lub wniosku bądź ilości wynikającej z zastosowania art. 45 ust. 3 lit. b rozporządzenia 2016/1240, umowy się nie zawiera. Agencja płatnicza powiadamia zwycięskiego przedsiębiorcę o uznaniu umowy za zawartą w ciągu 5 dni roboczych od wystawienia sprawozdania z kontroli pod warunkiem, że wpłynęły wszystkie dokumenty niezbędne do zawarcia umowy. Datą zawarcia umowy jest dzień, w którym agencja płatnicza powiadamia przedsiębiorcę. Art. 52 rozporządzenia 2016/1240 nakłada na przedsiębiorcę liczne obowiązki, w tym m.in.: obowiązek wprowadzenia i przechowywania ilości objętych umową w okresie przechowywania objętym umową na własne ryzyko oraz koszt w warunkach zapewniających utrzymanie cech produktów co do zasady bez zamieniania przechowywanych produktów na inne lub bez przenoszenia ich do innego miejsca prywatnego przechowywania; obowiązek umożliwienia agencji płatniczej kontroli w dowolnym czasie w celu sprawdzenia, czy zobowiązania zawarte $\mathrm{w}$ umowie są dotrzymywane ${ }^{22}$; obowiązek udostępnienia agencji płatniczej odpowiedzialnej za kontrolę wszelkich niezbędnych dokumentów; obowiązek prowadzenia w miejscu przechowywania rejestru umów według ich numerów,

${ }^{21} \mathrm{~W}$ angielskiej wersji tego rozporządzenia znalazło się sformułowanie Storage contract, w wersji niemieckiej - Lagerverträge, a we francuskiej - Contrats de stockage.

22 Przepisy szczegółowe dotyczące kontroli dopłat do prywatnego przechowywania zawiera art. 60 rozporządzenia 2016/1240, natomiast kary i środki administracyjne w odniesieniu do dopłat do prywatnego przechowywania regulowane są przez art. 62 tego rozporządzenia. 
z zapisywaniem dla każdej z nich identyfikacji produktów wprowadzonych do przechowywania, daty wprowadzenia do przechowywania i wydania z przechowywania, ilości produktów i umiejscowienia produktów w miejscu przechowywania.

\section{WYDANIE PRODUKTÓW I WYPŁATA DOPŁAT DO PRYWATNEGO PRZECHOWYWANIA}

Wydawanie z przechowywania można rozpocząć w dniu następującym po ostatnim dniu okresu przechowywania objętym umową lub ewentualnie od dnia określonego $\mathrm{w}$ rozporządzeniu wykonawczym otwierającym procedurę przetargową lub ustalającym z góry stawki dopłat do prywatnego przechowywania.

Przedsiębiorca składa wniosek o wypłatę w ciągu 3 miesięcy od zakończenia okresu przechowywania objętego umową. Wypłaty dopłat dokonuje się nie później niż 120 dni po dacie złożenia wniosku o wypłatę, pod warunkiem że spełniono wszystkie zobowiązania umowne. Jednak w przypadku, gdy podjęto postępowanie administracyjne, wypłatę wstrzymuje się do czasu uznania uprawnień do otrzymania dopłaty.

Zasady uzupełniające rozporządzenie 1308/2013 w odniesieniu do przyznawania dopłat do prywatnego przechowywania wieprzowiny zostały określone przepisami rozporządzenia 2016/1238. Zgodnie z nimi zasadniczo taką dopłatę wypłaca się w odniesieniu do ilości objętej umową, jeżeli ilość przechowywana w okresie przechowywania objętego umową stanowi co najmniej 99\% ilości objętej umową. Wyjątkowo, m.in. w odniesieniu do wieprzowiny, dopłatę wypłaca się w odniesieniu do ilości objętej umową, jeżeli ilość przechowywana w okresie przechowywania objętego umową stanowi co najmniej 97\% objętej umową ilości, która dotyczy świeżego mięsa wprowadzonego do miejsca przechowywania. Dopłaty są wypłacane jedynie w przypadku, gdy okres przechowywania objętego umową jest zgodny z okresem przechowywania określonym w rozporządzeniu wykonawczym otwierającym procedurę przetargową lub ustalającym z góry stawki dopłat.

Przepisy rozporządzenia 2016/1238 wskazują też na sytuacje, w których przedsiębiorca nie otrzyma dopłat $z$ tytułu przechowywania. Po pierwsze, dopłata nie zostanie wypłacona, jeżeli ilość przechowywana w okresie przechowywania objętego umową jest mniejsza niż odsetek ilości objętej umową, z wyjątkiem przypadków siły wyższej. Po drugie, nie wypłaca się tej dopłaty w przypadku danej umowy, jeśli nie został spełniony wymóg ustanowiony w art. 53 ust. 3 rozporządzenia 2016/124023.

${ }^{23}$ Zgodnie z przywołanym przepisem, jeżeli w rozporządzeniu wykonawczym otwierającym procedurę przetargową lub ustalającym z góry stawki dopłat okres przechowywania objętego umową określono jako pewną liczbę dni, podmiot gospodarczy powiadamia agencję płatniczą 
Ponadto przewidziana jest procedura zmniejszenia dopłaty. Mianowicie, z wyjątkiem przypadków siły wyższej, jeżeli przedsiębiorca nie przestrzega, w odniesieniu do łącznej przechowywanej ilości, terminu kończącego okres przechowywania objętego umową, dopłata za przedmiotową umowę zostaje zmniejszona o $10 \%$ za każdy dzień kalendarzowy przekraczający ten termin, aczkolwiek zmniejszenie to nie przekracza $100 \%$ dopłaty.

Istotną zmianą, w porównaniu do uprzednio obowiązujących unormowań, jest eliminacja instytucji jednorazowej zaliczki na poczet dopłaty, która w poprzednim stanie prawnym mogła być wypłacona pod pewnymi warunkami na wniosek strony zawierającej umowę ${ }^{24}$.

\section{PODSUMOWANIE}

Przyznawanie dopłat do przechowywania przez podmioty prywatne produktów pochodzących z obszaru UE jest instrumentem wspomagania właściwym dla określonych rynków branżowych, w tym dla rynku wieprzowiny. Nowe regulacje w zakresie prywatnego przechowywania na rynku wieprzowiny stanowią wyraz dążenia unijnego prawodawcy do stworzenia - metodą ewolucji - sprawniej działających i lepiej dostosowanych narzędzi zarządzania kryzysowego, aby sprostać dostrzeganym nowym wyzwaniom gospodarczym. Przyjęte zmiany normatywne nie zawierają rewolucyjnych zmian i zasadniczo stanowią kontynuację oraz opierają się na dotychczasowych rozwiązaniach.

\section{BIBLIOGRAFIA}

Budzinowski R., Status prawny rolnika jako przedsiębiorcy. Zagadnienia wybrane, „Ruch Prawniczy, Ekonomiczny i Socjologiczny" 2002, nr 3.

Czechowski P., Europejskie rynki rolne, [w:] Prawo rolne, Warszawa 2011.

Czechowski P., Proces dostosowywania polskiego prawa rolnego i żywnościowego do prawa Unii Europejskiej, Warszawa 2001.

Informacja Ministra Rolnictwa i Rozwoju Wsi na temat realizacji działań Agencji Rynku Rolnego w zakresie pakietu pomocowego Komisji Europejskiej, Warszawa 2016, www.senat.gov.pl/ gfx/senat/userfiles/_public/k9/komisje/2016/krrw/materialy/25pos/25pos_infmrrw.pdf [dostęp: 16.10.2016].

Jeżyńska B., Branżowa organizacja rynków rolnych, [w:] Prawo rolne i żywnościowe. Zarys wy$k ł a d u$, red. B. Jeżyńska, A. Oleszko, Kraków 2003.

Jeżyńska B., Producent rolny jako przedsiębiorca, Lublin 2008.

Komunikat Komisji Europejskiej z dnia 12 października 2011 r., http://europa.eu/rapid/press-release_IP-11-1181_pl.htm [dostęp: 15.10.2016].

o zamiarze podjęcia wycofywania produktów z przechowywania, wskazując odnośne partie/kadzie/silosy co najmniej na 5 dni roboczych przed rozpoczęciem operacji wydawania.

${ }^{24}$ Zob. art. 31 rozporządzenia Komisji (WE) nr 826/2008 przytoczonego w przypisie 1. 
Komunikat Komisji Europejskiej oficjalnie uznający za przestarzałe niektóre akty prawa unijnego w zakresie rolnictwa, Cel czwarty komunikatu Komisji z dnia 11 lutego 2003 r. w sprawie aktualizacji i uproszczenia wspólnotowego dorobku prawnego, $\operatorname{COM}(2003) 71$ wersja ostateczna (Dz.Urz. C 336 z 11 grudnia 2010 r.)

Kozikowska K., Agencja Rynku Rolnego i organizacja niektórych rynków rolnych, [w:] Prawo rolne, red. M. Jarosiewicz, K. Kozikowska, Kraków 2007.

Naworski J., Status prawny rolnika indywidualnego, „Przegląd Prawa Handlowego” 2012, nr 10.

Rozporządzenia delegowane KE (UE) 2016/1238 z dnia 18 maja 2016 r. uzupełniające rozporządzenie Parlamentu Europejskiego i Rady (UE) nr 1308/2013 w odniesieniu do interwencji publicznej i dopłat do prywatnego przechowywania (Dz.Urz. L 206 z 30 lipca 2016 r.).

Rozporządzenie Komisji (EWG) nr 1092/80 z dnia 2 maja 1980 r. ustanawiające szczegółowe zasady przyznawania pomocy w odniesieniu do prywatnego składowania wieprzowiny (Dz.Urz. L 114 z 3 maja 1980 r.).

Rozporządzenie Komisji (EWG) nr 3444/90 z dnia 27 listopada 1990 r. ustanawiające szczegółowe zasady dotyczące przyznawania pomocy w odniesieniu do prywatnego składowania wieprzowiny (Dz.Urz. L 333 z 30 listopada 1990 r.).

Rozporządzenie Komisji (WE) nr 2042/98 z dnia 25 września 1998 r. w sprawie specjalnych warunków przyznawania pomocy w odniesieniu do prywatnego przechowywania wieprzowiny (Dz.Urz. L 263 z 26 września 1998 r.).

Rozporządzenie Komisji (WE) nr 2713/1999 z dnia 20 grudnia 1999 r. wprowadzające odstępstwo od rozporządzenia (EWG) nr 3444/90 ustanawiającego szczegółowe zasady dotyczące przyznawania pomocy w odniesieniu do prywatnego składowania wieprzowiny (Dz.Urz. L 327 z 21 grudnia 1999 r.).

Rozporządzenie Komisji (WE) nr 2179/2002 z dnia 6 grudnia 2002 r. w sprawie szczególnych warunków przyznawania pomocy w odniesieniu do prywatnego składowania wieprzowiny (Dz.Urz. L 331 z 7 grudnia 2002 r.).

Rozporządzenie Komisji (WE) nr 2246/2003 z dnia 19 grudnia 2003 r. w sprawie szczególnych warunków przyznawania pomocy w odniesieniu do prywatnego składowania wieprzowiny (Dz.Urz. L 333 z 20 grudnia 2003 r.).

Rozporządzenie Komisji (WE) nr 1267/2007 z dnia 26 października 2007 r. w sprawie szczególnych warunków przyznawania pomocy w odniesieniu do prywatnego składowania wieprzowiny (Dz.Urz. L 283 z 27 października 2007 r.).

Rozporządzenie Komisji (WE) nr 179/2008 z dnia 28 lutego 2008 r. umożliwiające przedłużenie okresu obowiązywania umów o prywatne przechowywanie w sektorze wieprzowiny (Dz.Urz. L 56 z 29 lutego 2008 r.).

Rozporządzenie Komisji (WE) nr 1278/2008 z dnia 17 grudnia 2008 r. w sprawie przyjęcia nadzwyczajnych środków wsparcia rynku wieprzowiny w formie dopłat do prywatnego przechowywania w Irlandii (Dz.Urz. L 339 z 18 grudnia 2008 r.).

Rozporządzenie Komisji (WE) nr 826/2008 z dnia 20 sierpnia 2008 r. ustanawiające wspólne zasady dotyczące przyznawania dopłat do prywatnego przechowywania niektórych produktów rolnych (Dz.Urz. L 223 z 21 sierpnia 2008 r.).

Rozporządzenie Rady nr 121/67/EWG (5) z dnia 13 czerwca 1967 r. w sprawie wspólnej organizacji rynku wieprzowiny (Dz.Urz. 117 z 19 czerwca 1967 r.).

Rozporządzenie Rady (EWG) nr 2759/75 z dnia 29 października 1975 r. w sprawie wspólnej organizacji rynku wieprzowiny (Dz.Urz. L 282 z 1 listopada 1975 r.).

Rozporządzenie Rady (WE) nr 1234/2007 z dnia 22 października 2007 r. ustanawiające wspólną organizację rynków rolnych oraz przepisy szczegółowe dotyczące niektórych produktów rolnych (,rozporządzenie o jednolitej wspólnej organizacji rynku”, Dz.Urz. L 299 z 16 listopaada 2007 r.). 
Rozporządzenie wykonawcze Komisji (UE) nr 68/2011 z dnia 28 stycznia 2011 r. w sprawie ustalania $\mathrm{z}$ wyprzedzeniem stawek dopłat do prywatnego przechowywania wieprzowiny (Dz.Urz. L 26 z 29 stycznia 2011 r.).

Rozporządzenie wykonawcze Komisji (UE) nr 192/2011 z dnia 25 lutego 2011 r. ustanawiające specjalne środki w odniesieniu do dopłat do prywatnego przechowywania wieprzowiny przewidzianych w rozporządzeniu (UE) nr 68/2011 (Dz.Urz. L 53 z 26 lutego 2011 r.).

Rozporządzenie wykonawcze Komisji (UE) nr 197/2011 z dnia 28 lutego 2011 r. ustanawiające ostateczny termin składania wniosków o przyznanie dopłat z tytułu przechowywania wieprzowiny na mocy rozporządzenia (UE) nr 68/2011 (Dz.Urz. L 56 z 1 marca 2011 r.).

Rozporządzenie wykonawcze Komisji (UE) 2015/360 z dnia 5 marca 2015 r. wprowadzające prywatne przechowywanie wieprzowiny oraz ustalające z góry stawkę dopłat (Dz.Urz. L 62 z 6 marca 2015 r.).

Rozporządzenie wykonawcze Komisji (UE) 2015/679 z dnia 29 kwietnia 2015 r. zawieszające składanie wniosków o dopłaty do prywatnego przechowywania wieprzowiny przewidziane w rozporządzeniu wykonawczym Komisji (UE) 2015/360 (Dz.Urz. L 111 z 30 kwietnia 2015 r.).

Rozporządzenie wykonawcze Komisji (UE) 2015/725 z dnia 5 maja 2015 r. ustanawiające ostateczny termin składania wniosków o przyznanie dopłat do prywatnego przechowywania wieprzowiny na mocy rozporządzenia wykonawczego (UE) 2015/360 (Dz.Urz. L 115 z 6 maja 2015 r.).

Rozporządzenie wykonawcze 2015/2334 z dnia 14 grudnia 2015 r. wprowadzające prywatne przechowywanie wieprzowiny oraz ustalające z góry stawkę dopłat (Dz.Urz. L 329 z 15 grudnia 2015 r.).

Rozporządzenie wykonawcze 2016/85 z dnia 25 stycznia 2016 r. zawieszające składanie wniosków o przyznanie dopłat do prywatnego przechowywania wieprzowiny przewidzianych w rozporządzeniu wykonawczym (UE) 2015/2334 (Dz.Urz. L 17 z 26 stycznia 2016 r.).

Rozporządzenie wykonawcze 2016/132 z dnia 1 lutego 2016 r. ustanawiające ostateczny termin składania wniosków o przyznanie dopłat do prywatnego przechowywania wieprzowiny na mocy rozporządzenia wykonawczego (UE) 2015/2334 (Dz.Urz. L 25 z 2 lutego 2016 r.).

Szewczak M., Administracyjno-prawne aspekty realizacji Wspólnej Polityki Rolnej w Polsce, Lublin 2008.

Tomkiewicz E., Dopłaty do prywatnego przechowywania produktów rolnych, [w:] Prawo i polityka rolna Unii Europejskiej, red. A. Jurcewicz, Warszawa 2010.

Tomkiewicz E., Dopłaty z tytułu prywatnego przechowywania produktów rolnych, [w:] Wspólna polityka rolna. Zagadnienia prawne, red. A. Jurcewicz, B. Kozłowska, E. Tomkiewicz, Warszawa 2007.

Uchwała SN z dnia 26 lutego 2015 r., III CZP 108/14, OSNC 2016, nr 1, poz. 2.

Uzasadnienie wniosku rozporządzenia Parlamentu Europejskiego i Rady ustanawiające wspólną organizację rynków produktów rolnych (,rozporządzenie o jednolitej wspólnej organizacji rynków”), COM/2011/0626, wersja ostateczna - 2011/0281 (COD), http://eur-lex.europa.eu/ legal-content/PL/TXT/?uri=CELEX:52011PC0626 [dostęp: 15.10.2016].

Wyrok SN z dnia 3 października 2014 r., V CSK 630/13, OSNC 2015, nr 7-8, poz. 96.

Zaręba P., Bolisęga E., Nowe zasady interwencji na rynkach rolnych Unii Europejskiej, „Biuletyn Informacyjny ARR”2016, nr 2.

\section{SUMMARY}

This study focuses on the pigmeat market as one of the agricultural markets within the Common Agricultural Policy. The main mechanisms for intervening in the EU related to this market include public intervention and aid for private storage. The purpose of the aid for private storage is temporary blocking of surplus of pigmeat on the market when oversupply causes unfavourable 
price relations. In contrast to public intervention, the system of aid for private storage does not transfer the ownership of pigmeat to a paying agency. In exchange for the aid for storage the operator undertakes to store the product for the time specified in the agreement and to refrain from placing it on the market. The article deals with the normative provisions for the operators within the system of aid for private storage of pigmeat resulting primarily from the Regulation (EU) No. 1308/2013 of the European Parliament and of the Council of 17 December 2013 establishing a common organisation of the markets in agricultural products and repealing Council Regulations (EEC) No. 922/72, (EEC) No. 234/79, (EC) No. 1037/2001 and (EC) No. 1234/2007 as well as the Commission Delegated Regulation (EU) 2016/1238 of 18 May 2016 supplementing Regulation (EU) No. 1308/2013 of the European Parliament and of the Council with regard to public intervention and aid for private storage, which entered into force on 1 October 2016 and Commission Implementing Regulation (EU) 2016/1240 of 18 May 2016 laying down rules for the application of Regulation (EU) No. 1308/2013 of the European Parliament and of the Council with regard to public intervention and aid for private storage.

Keywords: aid for private storage; pigmeat market; operator; Common Agricultural Policy 